ATHEIST DELUSIONS 

DAVID BENTLEY HART

\section{Atheist Delusions}

THE CHRISTIAN REVOLUTION AND ITS FASHIONABLE ENEMIES 
Published with assistance from the Mary Cady Tew Memorial Fund.

Copyright (C) 2009 by David Bentley Hart.

All rights reserved.

This book may not be reproduced, in whole or in part, including illustrations, in any form (beyond that copying permitted by Sections 107 and 108 of the U.S. Copyright Law and except by reviewers for the public press), without written permission from the publishers.

Set in FontShop Scala and Scala Sans by Duke \& Company, Devon, Pennsylvania.

Printed in the United States of America by Sheridan Books, Ann Arbor, Michigan.

The Library of Congress has cataloged the hardcover edition as follows:

Hart, David Bentley.

Atheist delusions : the Christian revolution and its fashionable enemies / David Bentley

Hart.

p. $\mathrm{cm}$.

Includes bibliographical references and index.

ISBN 978-0-300-11190-3 (cloth : alk. paper) 1. Church history-Primitive and early church, ca. 30-600. 2. Civilization, Western. 3. Christianity-Influence. I. Title.

BR162.3.H37 2009

909'.09821-dc22 2008040641

ISBN 978-0-300-16429-9 (pbk.)

A catalogue record for this book is available from the British Library.

$\begin{array}{llllllllll}10 & 9 & 8 & 7 & 6 & 5 & 4 & 3 & 2 & 1\end{array}$ 
For Solwyn 
